JBT, Volume-XI, No-01\& 02, January-December, 2016

\title{
Impact of Money, Interest Rate and Inflation on Dhaka Stock Exchange (DSE) of Bangladesh \\ SHAKIRA MAHZABEEN*
}

\begin{abstract}
In this study, the impact of money supply, interest rate and inflation on Dhaka Stock Exchange (DSE) of Bangladesh is explored. These macroeconomic variables are said to have strong impact on capital market. The purpose of this study is to find out if it is true for Dhaka Stock Exchange. For this purpose, data were collected for a period of twelve years from January 2001 to December 2012, on 144 variables. Broad money supply (M2) has been taken as a measure of money supply, 91-days T-bill has been taken as a measure of short-term interest rate and CPI general inflation rate (Base: 1995=100) has been taken as a measure of inflation rate. Apart from that many rules and regulations were reviewed. As to the relationship of the market indices, month-end DGEN Index and its percentage change were used in this paper. A unit root test has been done to see the stationarity of the variables because stationary data are needed for the analysis. A pairwise correlation matrix shows that there was no multicolinearity problem. A simple OLS regression indicates a relationship with money growth, interest rate. But Granger causality test shows that there is only a slight relationship with short term interest rate, nothing else. Overall though a short-run relationship is found between interest rate and market index; the relationship is not very strong. It is proposed that a study estimating long run impact of the explanatory variables should be taken up to know the full effect.
\end{abstract}

Key Words: Money supply, Interest rate, Inflation, Stock market, Time series model

\footnotetext{
${ }^{*}$ Lecturer, Green Business School, Green University of Bangladesh (GUB), Dhaka
} 


\section{INTRODUCTION}

The purpose of monetary policy is to find out a proper mix of macroeconomic variables which will attain desirable economic growth through various macroeconomic variables. Money and interest rate are the two most important instruments through which central bank can control and boost economic activities. Whether the monetary policy will be expansive or restrictive depends on the current economic and market conditions of that particular economy. A slightest change in monetary policy will affect the financial market at a much faster pace and larger scale. But all markets do not react in the same pace and at the same level of intensity. That is why it is important to understand the impact of monetary policy on different asset prices as these assets ultimately lead to economic growth.

Stock market is a key indicator of economic development. If stock market is liquid and liberalized, it can foster long term growth (Fuchs-Schundeln and Funke, 2003); and stock price movement defines economic growth (Olweny and Kimani, 2011). But if in small economies like Bangladesh where stock market is shallow, it does not predict economic development (Ahmed and Imam, 2007). To contribute to economic development, it has to be ensured that investors get desirable returns from it. In that respect, Dhaka Stock Exchange is not weak-form efficient (Hasan, 2004), but a counter argument is given by Islam and Khaled (2005) who found that it was weak-form efficient after the crash of 1996 due to steps taken by Securities and Exchange Commission.

There has been an argument about the relationship of stock market return and monetary variables. Each year Bangladesh Bank announces monetary policy statement addressing the crucial issues of the economy. Based on the policy statement, Bangladesh Bank adjusts the monetary and macroeconomic variables to attain the goals statement. On the basis of the monetary policy, investors adjust their portfolio which ultimately adjusts the stock market index. It is said that the extent of monetary policy will depend on the liquidity conditions of the stock market (Wright, 1976).

In a restrictive monetary policy regime, central bank will sell different government instruments to the public and take out a large amount of money from the market. On the other hand, it will increase the interest rate so that borrowers find it costly to take loans from the banks. In an expansive monetary policy, central bank will provide more money to the public by buying back different securities and also by decreasing the interest rate. In an expansionary monetary policy, borrowers find investments less costly and people have more money to spend. This leads to addition in GDP and economic growth increases. But on the 
negative side, this will lead to an increase in the level of inflation and expected inflation.

A higher level of expected inflation is worse than actual inflation. Thus a consecutive rise in inflation will increase the level of expected inflation. A high level of inflation reduces the purchasing power of money. This means people have to spend additional money to buy something than before. In such a situation, businesses cannot expand because investment is costly and people cannot invest as they have less money left as savings. This scenario affects stock markets along with other markets in an economy. To get rid of this situation, monetary policy-makers adopt restrictive monetary policy. The core purpose of this type of policy is to control inflation within tolerable range.

No matter what purpose monetary policy wants to serve, it has an impact on the stock market. Whether the impact is significant or not is the main concern. Many studies have conducted to see if monetary policy has any significant impact on the stock market return or not. Different studies have shown different outcomes. Some showed that monetary policy has a small or insignificant impact on stock market returns and some showed that it has a significant impact. This paper deals with this problem and tries to focus on finding if such a relationship really exits.

\section{LITERATURE REVIEW}

According to Thorbecke (1997), monetary policy is not neutral. Using vector autoregression (VAR) model, he showed that monetary policy indicators exerted real and important effects on stock returns, at least in the short run. He found that in every case expansionary monetary policy had strong effect on the ex-post stock returns. Multi-factor model revealed that the same was true for the ex-post returns as well. This implies the fact that monetary policy affects the accessibility conditions of the firms. Patelis (1997) tried to find out long and short horizon effect of monetary policy on stock returns. He revealed that in the long run, monetary policy indicators had significant impact on future returns. Bomfim (2000) on the other hand found that stock markets tend to be less volatile to the policy announcements on preceding days of announcements.

Chen (2007), in his paper, used Standard and Poor's 500 index. Using monthly returns of this index, he tried to find out the impact of monetary policy on the stock market using Markov-switching models. He found that monetary policy had asymmetric effects on stock returns. Ivrendi and Guloglu (2012) conducted study in six Asian countries and found the same result. But Laopodis (2006) in his study revealed that there was no consistent relationship between 
monetary policy and stock prices. He explored that there might be relationships existing in any particular regime, but it did not last consistently.

In his paper, Blanchard (1981) worked using output, stock market and interest rate. His study showed that neither stock market nor output changed each other. It was the policy that caused the change in the stock market and output level. Whether policy about interest rate was anticipated or not, it led to a change in the overall stock market. Chancharoenchai et al. (2005) in their study used six Asian countries and their stock markets to see the impact of interest rate on stock market. They used data of stock returns, treasury bills and government bonds from January 1987 to December 1996. Using auto-regressive conditional heteroskedasticiy-type model, they revealed that interest rate had some predictive power in case of predicting excess returns. Thus monetary policy measured by interest rate had significant impact on stock market and stock returns (Ioannidis and Kontonkas, 2008).

Hashemzadeh and Taylor (1988) found the causality between money supply and stock prices, and between the levels of interest rate and stock prices. Their study showed that money supply caused some of the variations in the stock market and stock market caused some variations in the money supply expectations. That is, they had a bi-directional causality. Boyle (1990) found that the changes in the monetary growth would change the expectations about the real equity returns and inflation. Thus changes in the monetary aggregates would change the equity risk premium.

Adams et al. (2004) tried to find out whether stock return was affected by the unanticipated stock return. In doing this, they tried to answer several questions. They found that unexpected increases in both producer price index (PPI) and consumer price index (CPI) made stock prices fall. Davis and Kutan (2003) in their study took 13 developed and developing countries to see if macroeconomic variables could predict the stock market return in advance. Using GARCH models, they found no strong evidence of such predictive power. They revealed that macroeconomic variables, which were measured by movements in inflation and real output had insignificant contribution in forecasting the future stock returns. They found that stock returns were sensitive to inflation only in the USA, when three-month horizon was used and an additional country joined the list when six-month horizon was used. Tas (2009) said the monetary policy influenced the expectation about future inflation and output, which ultimately changed the stock returns. 


\section{METHODOLOGY AND DATA COLLECTION}

To measure the impact of monetary policy on stock market, different researchers used different variables. The most common two variables were money supply and interest rate. In this paper, T-bill rate was used as short term interest rate (Chancharoenchai, Dibooglu and Mathur, 2005) (Patelis, 1997) alongside money supply (Wong, Khan and Du, 1987) (Mookerjee, 1987) to measure the impact of monetary policy on Dhaka Stock market. In this paper Broad money or M2 was taken as a measure of money supply, 91-days T-bill rate is taken as a short term risk-free interest rate. Annualized rate of monthly inflation (Ateseglu, 2008) was considered as well.

To understand the role of a stock exchange, Alam and Uddin (2009) took monthly data from 1988 to 2003 for fifteen developed and developing countries including Bangladesh, and found that interest rate had significant negative relationship with stock market. That is, if interest rate could be controlled, it could be used as a medium to increase the participation in the stock market and could push more investable fund to the companies for further expansion.

Nguyen et al. (2011), in their study worked on Dhaka Stock Exchange to see the effect of monetary policy on the stock market return. They took narrow money (M1) as the indicator of monetary policy and found that stock prices reacted according to the monetary policy. They revealed that stock prices reacted more rapidly to a contractionary monetary policy which was led by the decline in the money supply and reacted less rapidly to an expansionary monetary policy. Their result also suggests that, firms which were more dependent on the stock market were more vulnerable to the business cycle change. On the other hand, they found that in the short-run monetary policy did not affect the stock prices. They explained it as the lack of investors' confidence on the active role of the central bank to carry out a policy as stated.

In this paper, attempt was made to find a relationship between monetary policy variables and stock market in Bangladesh, as well as inflation and stock market using DGEN Index. For this purpose, different statistical and econometric methods were used. At first, a set of summary statistics was estimated to get an overview of all the variables. Then a pairwise correlation matrix was built up to see the relationship among the variables and if there is any significant relationship between stock return and monetary variables. A unit root test was conducted to test the stationarity of the variables. 
An Ordinary Least Square (OLS) regression model as stated in equation (1) was estimated.

$S R_{t}=\alpha_{t}+\beta_{1} M 2 G_{t}+\beta_{2}$ Tbill $_{t}+\beta_{3} I N F_{t}+\varepsilon_{t}$

Where,

SR = Stock Return on DGEN

$M 2 G=$ Money Growth (M2)

Tbill $=$ 91-days $T$-bill Rate

INF = Inflation Rate

Granger Causality Test was done to see the causality among the variables. The methodology that was used was based on Engle and Granger (1987).

Data used in this paper included variables that were directly controlled by the central bank of Bangladesh along with data about the index of Dhaka Stock Exchange. Additionally, inflation rate data was collected to see the effect of inflation in the relationship of variables and stock market return. Monthly data were collected for a period from January 2001 to December 2012 (144 observations). The monetary policy variables data were collected from Economic Trend and Monthly Major Economic Indicators published by Bangladesh Bank, and stock market related data were collected from Dhaka Stock Exchange (DSE). As a new index system from 2013 as DSEX, but it was not possible to gather any long term data from it, DGEN Index was used as a measure of market price. Index price that was used is the closing price of the index on the last trading day of each month. Inflation rate taken was measured using point to point basis consumer price index with a base value of 100 (1995-1996).

\section{ANALYSIS AND INTERPRETATION}

Table 1 shows the summary of the variables taken for this study. The total number of observations of this study was 144 . Data were taken monthly for a period of 12 years (from January 2001 to December 2012). There was no missing data in this study. So for all variables, total number of observations was 144 . In case of using time-series data, there are a number of econometric issues that are important. Because of the presence of non-stationary data, running OLS regression estimations may create problem in Durbin-Watson test, t-Statistics or R-Square. Therefore, prior to testing and implementing econometric models, the test of stationarity (unit root) is important. A series was said to be stationary if the mean and variance are time-variant, and a series was said to be nonstationary, if the mean and variance was time dependent. 
To test the unit root two types of test were implemented. The first one was Augmented Dickey-Fuller Unit Root Test and another is Phillips-Perron Unit Root Test. If the ADF t-statistic is less than the t-statistic of Mackinnon critical tvalues, then the null hypothesis of unit root cannot be rejected and it can be said that the series is non-stationary at their level. The PP test is almost similar to ADF test except that it tests the non-parametric unit root test. From the Unit root test it was found that DGEN return, money growth, log T-bill and log inflation followed random walk. Due to space constraint, the table is not shown here.

TABLE 1

SUMMARY STATISTICS

\begin{tabular}{|c|c|c|c|c|c|c|}
\hline & DGEN price & $\begin{array}{c}\text { DGEN } \\
\text { Return }\end{array}$ & $\begin{array}{c}\text { Money } \\
\text { Supply }\end{array}$ & $\begin{array}{c}\text { Money } \\
\text { Growth }\end{array}$ & $\begin{array}{c}\text { T-bill } \\
\text { Rate }\end{array}$ & \begin{tabular}{c} 
Inflation \\
\hline Observation
\end{tabular} \\
\hline Mean & 2682.368 & 0.0130679 & 232615.7 & 0.0133907 & 0.065924 & 0.071779 \\
\hline SD & 1994.635 & 0.079615 & 134498 & 0.0149589 & 0.02222 & 0.02905 \\
\hline Maximum & 8602.44 & 0.2640576 & 551155.8 & 0.083158 & 0.1137 & 0.1197 \\
\hline Minimum & 607.43 & -0.3635474 & 81100.9 & -0.0340995 & 0.0111 & 0.0124 \\
\hline
\end{tabular}

\section{Pairwise Correlation}

Table 2 represents the pairwise correlation of the variables used in this paper. It shows that correlation of DGEN return and M2 growth, T-bill rate and inflation was $0.16,-0.26$ and -0.01 respectively. But among these three DGEN return and T-bill rate had significant correlation at 5\% level of significance. On the other hand, independent variables did not have any significant correlation with each other. The result shows that the correlation between M2 growth and T-bill rate was -0.04 , correlation between M2 growth and inflation was 0.12 and correlation between T-bill rate and inflation was -0.02 and none of the correlation was significant at even $1 \%$ level of significance. This suggests that there was no multicolinearity problem among the independent variables. 
TABLE 2

PAIRWISE CORRELATION BETWEEN DGEN RETURN AND M2 GROWTH, M2 GROWTH AND T-BILL RATE, T-BILL RATE AND INFLATION

\begin{tabular}{|l|l|l|l|l|}
\hline & DGEN Return & M2 Growth & T-bill Rate & Inflation \\
\hline $\begin{array}{l}\text { DGEN } \\
\text { Return }\end{array}$ & 1 & & & \\
\hline $\begin{array}{l}\text { M2 } \\
\text { Growth }\end{array}$ & 0.1602 & 1 & & \\
\hline T-bill Rate & $-\mathbf{0 . 2 5 6 2 *}$ & & 1 & \\
\hline Inflation & -0.0136 & -0.0381 & -0.0162 & 1 \\
\hline
\end{tabular}

Note: * represents significance at $5 \%$ level.

\section{OLS Regression}

Table 3 presents the result of OLS regression of DGEN return against money growth, interest and inflation. The Durbin-Watson Test was performed to measure the autocorrelation problem. The test suggests that there was no autocorrelation as the value stated at 2.10 . The constant coefficient was 0.15 and it was significant at $1 \%$ level of significance. This means that $1 \%$ return this period would lead to get a return of 15\% in the next period, given that all other variables are constant. The coefficient of money growth is 0.80 and the p-value was 0.07 . This means that if money growth was increased by $1 \%$ the stock return would increase by $0.80 \%$ at $10 \%$ level of significance. This indicates that broad money growth affected stock return to some extent. In case of interest rate, the coefficient was -0.05 and the $\mathrm{p}$-value were 0.002 . This means that if interest rate increase by $1 \%$ the stock return would decrease by $.048 \%$. From the coefficient it is noticeable that short term interest rate is negatively related with stock return, which explained the decrease in stock return in case of a short percentage change in T-bill rate. As in the case of inflation, the result shows that there was no significant relationship between inflation and stock return. Though the relationship was negative, but the coefficient was not statistically significant even at $10 \%$ level of significance. 
TABLE 3

OLS REGRESSION RESULT FOR DGEN RETURN AGAINST MONEY

GROWTH, INTEREST AND INFLATION

\begin{tabular}{|l|l|l|}
\hline Variables & Coefficient & P-Value \\
\hline M2 Growth & $.8029616^{*}$ & 0.065 \\
\hline LnT-Bill Rate & $-.0476657^{* * *}$ & 0.002 \\
\hline LnInflation & -.0078008 & 0.516 \\
\hline Constant & $.1523005^{* * *}$ & 0.008 \\
\hline F-Statistics & 0.0039 \\
\hline Durbin-Watson Test & 2.099743 \\
\hline
\end{tabular}

Note: $* * * * *, *$ represents significance level at $1 \%, 5 \%$ and $10 \%$ respectively.

\section{Granger Causality Test}

The next analysis done was Granger causality relationship test between the DGEN return and the macro economic variables. This result is shown in Table 4. The Table shows that there was no significant Granger causality between DGEN return and money growth. Causality in both the directions between DGEN return and money growth was not significant. But there was a unidirectional causality from DGEN return to T-bill rate. That was DGEN returns influenced T-bill rate at $1 \%$ level of significance. But the reverse is not true at least within the time period. Neither DGEN return nor inflation had any significant causality between them.

The same was true for money growth and T-bill rate. That is neither money growth nor T-bill rate had any significant influence on each other. Money growth had a unidirectional causality with inflation. That is, a change in money growth would affect inflation and the causality was true at $5 \%$ level of significance. But inflation did not influence money growth. In case of T-bill rate and inflation, there was bidirectional causality between them. T-bill rate had an impact on inflation at 5\% level of significance and inflation had an impact on T-bill rate at $1 \%$ level of significance. This indicated an important implication of central bank policy. It is the interest rate by which central bank can influence and direct the level of inflation in Bangladesh. 
TABLE 4

GRANGER CAUSALITY TEST AMONG DGEN RETURN, M2 GROWTH, T-BILL RATE AND INFLATION

\begin{tabular}{|c|c|c|c|c|}
\hline \multicolumn{2}{|c|}{ Direction of causality } & Chi Square & P-Value \\
\hline Return & $\neq>$ & M2 Growth & 5.8402 & 0.4413 \\
\hline M2 Growth & $\neq>$ & DGEN Return & 6.1483 & 0.4068 \\
\hline DGEN & $=>$ & T-Bill Rate & $\mathbf{1 9 . 0 7 6 1 ^ { * * * * }}$ & $\mathbf{0 . 0 0 4}$ \\
Return & & & & 0.8595 \\
\hline T-bill Rate & $\neq>$ & DGEN Return & 2.5791 & 0.2844 \\
\hline DGEN & $\neq>$ & Inflation & 7.4122 & 0.5416 \\
Return & & & & 0.4959 \\
\hline Inflation & $\neq>$ & DGEN Return & 5.017 & 0.771 \\
\hline M2 Growth & $\neq>$ & T-Bill Rate & 5.3811 & $\mathbf{0 . 0 7 7 9}$ \\
\hline T-bill Rate & $\neq>$ & M2 Growth & 3.2954 & 0.9053 \\
\hline M2 Growth & $\Rightarrow>$ & Inflation & $\mathbf{1 1 . 3 5 8 2 * *}$ & $\mathbf{0}$ \\
\hline Inflation & $\neq>$ & M2 Growth & 2.1511 & $\mathbf{0 . 0 0 0 2}$ \\
\hline T-bill Rate & $\Rightarrow>$ & Inflation & $\mathbf{6 7 . 3 5 5 6 * * *}$ & $\mathbf{2 6 . 8 0 2 3 * * *}$ \\
\hline Inflation & $\neq>$ & T-Bill Rate & & \\
\hline
\end{tabular}

Notes:

a) T-bill and Inflation is transformed into their natural logarithm.

b) $* * *, * *, *$ represents significance level at $1 \%, 5 \%$ and $10 \%$ respectively.

c) => implies the direction of causal relationship.

d) $\neq>$ implies lack of causal relationship.

This paper analyzed the dynamic relationship among money growth, short term interest, inflation and stock market return in the short run. Different measures and models were adopted to identify the relationships among these variables.

A simple correlation matrix showed no significant relationship among any of the variables except stock market return and short term interest rate measured by 91-days T-bill rate. OLS regression indicated that both money growth and interest rate affected stock market returns significantly. But the extent of interest rate was higher than money growth. Lastly, Granger causality test viewed that stock market return did have an one way causality with interest rate but no 
causality with either money supply or inflation rate. None of the analysis showed any kind of significant relationship between inflation rate and stock market return.

The first objective of this report was to find out the relationship between stock market return and money supply. Using different models, it was found that there was no significant relationship between these two variables. Thus money supply did not have any impact on determining the stock market returns at all and stock market was independent of money supply measured by M2.

The second objective was to find out the relationship between stock market return and short term interest rate. Almost all of the models proved the existence of a relationship between these two variables. Though the extent of the impact was very low, but there existed a relationship between them. It is difficult to say if the relationship would exist in the long run, but in the short run stock market was affected by the interest rate negatively.

The third objective was to find out if inflation played any role in determining the stock return. All the models rejected the possibility. Each and every model showed that inflation rate played a very insignificant role in the stock market.

Moreover, results showed that money supply was not correlated with either interest rate or inflation. But interest rate and inflation showed a two-way relationship with each other. That is, both interest rate and inflation were affected by each other.

\section{CONCLUSIONS AND POLICY IMPLICATIONS}

With the transformation of economic structure, polices and processes, capital market has become an important source of funding for businesses, entrepreneurs and investors. The Government and central bank play very significant roles in this reared by providing both the investors and businesses a proper and wellfunctioning capital market. But in an emerging market like Dhaka Stock Exchange where there are many anomalies, proper functioning by the authority is doubtful. This paper tried to find out the influence of central bank on stock market by means of money supply, interest rate and inflation.

This paper examined the relationship between stock returns and money supply, interest rate and inflation in Dhaka Stock Exchange during the time period of 2001 to 2012. The results indicated that only interest rate had a relationship with the stock returns and could affect stock returns negatively. Other than that, money supply and inflation did not have any significant impact on percentage change in index. But it could not be asserted strongly because the 
$\mathrm{R}$-square was quite weak for the variables. This indicates that, though the interest rate was significant, the long-term relationship was not quite certain.

Our stock market is not very efficient. As a result, the market does not react or respond to the changes in the monetary variables such as broad money and interest rate. If the market had been efficient, the market would have responded to these variables along with the macroeconomic variables like GDP and inflation. Though a short-run relationship was found between short-term interest rate and market index the relationship was not that much strong and a long-run impact measurement was needed.

Based on this paper, a number of suggestions can be recommended. If these are implemented, the stock market will become more efficient and may contribute to the economy in a bigger way. Regulators should give more attention to making the market more efficient, so that the stationary problem no longer exists. If this is implemented, the stock prices will take a more random walk and the scope of getting an abnormal return will narrow down. As interest rate has an impact on index change, Bangladesh Bank should take more care in determining interest rates.

\section{REFERENCES}

Adams, G., McQueen, G., and Wood, R. (2004). The Effects of Inflation on High Frequency Stock Returns. The Journal of Business, 77 (3), 547-574.

Ahmed, M. N., and Imam, M. O. (2007). Macroeconomic Factors and Bangladesh Stock Market: Impact Analysis through Co integration Approach. International Review of Business Research Papers, 3 (5), 21-35.

Alam, M. M., and Uddin, M. G. (2009). Relationship between Interest Rate and Stock Price: Empirical evidence from Developed and Developing Countries. International Journal of Business and Management, 4 (3), 43-51.

Ateseglu, H. S. (2008). Equity Returns and Monetary Policy. International Journal of Political Economy, 37 (2), 71-81.

Blanchard, O. J. (1981). Output, the Stock Market, and Interest Rate. The American Economic Review, 71 (1), 132-143.

Bomfim, A. N. (2000). Pre-Announcement Effects, News, and Volatility: Monetary Policy and the Stock Market. FEDS Working Paper No. 00-50. 
Boyle, G. W. (1990). Money Demand and the Stock Market in a General Equilibrium Model with Variable Velocity. Journal of Political Economy, 98 (5), 1039-1053.

Chancharoenchai, K., Dibooglu, S., and Mathur, I. (2005). Stock Returns and the Macroeconomic Environment Prior to the Asian Crisis in Selected Southeast Asian Countries. Emerging Markets Finance and Trade, 41 (4), 38-56.

Chen, S.-S. (2007). Does Monetary Policy Have Asymmetric Effects on Stock Returns? Journal of Money, Credit and Banking, 39 (2), 667-688.

Davis, N., and Kutan, A. M. (2003). Inflation and Output as Predictors of Stock Returns and Volatility: International evidence. Applied Financial Economics, 13, 693-700.

Engle, R., and Granger, C. (1987). Cointegration and Error Correction: Representation, Esimation and Testing. Econometrica, 55, 251-330.

Fuchs-Schundeln, N., and Funke, N. (2003). Stock Market Liberalizations: Financial and Macroeconomic Implications. Review of World economics, 139 (4), 730-761.

Hasan, M. (2004). On the Validity of the Random Walk Hypothesis Applied to the Dhaka Stock Exchange. International Journal of Theoritical and Applied Finance, 7 (8), 1069-1085.

Hashemzadeh, N., and Taylor, P. (1988). Stock Prices, Money Supply, and Interest Rates: the Question of Causality. Applied Economics, 20, 1603-1611.

Ioannidis, C., and Kontonokas, A. (2008). The Impact of Monetary Policy on Stock Prices. Journal of Policy Modeling, 30 (1), 33-53.

Islam, A., and Khaled, M. (2005). Tests of Weak-Form Efficiency of the Dhaka Stock Exchange. Journal of Business Finance and Accounting, 32 (7 and 8), 1613-1624.

Ivrendi, M., and Guloglu, B. (2012). Changes in Stock Price Volatility and Monetary Policy Regimes: Evidence from Asian Countries. Emerging Markets Finance and Trade, 48 (4), 54-70.

Laopodis, N. T. (2006). Dynamic Interactions among the Stock Market, Federal Fund Rate, Inflation and Economic Activity. The Financial Review, 41 (4), 513-545.

Nguyen, C. V., Islam, A. M., and Ali, M. m. (2011). Bangladeshi Naroow Money Supply and Equity Returns: An Assymetric Co-Integration Analysis. International Review of Business Research Papers, 7 (6), 84-100. 
Olweny, T. O., and Kimani, D. (2011). Stock Market Performance and Economic Growth: Empirical Evidence from Kenya Using Causality Test Approach. Advances in Management and Applied Economics, 1 (3), 177-220.

Patelis, A. D. (1997). Stock Return Predictability and The Role of Monetary Policy. Journal of Finance, 52 (5), 1951-1972.

Tas, B. K. (2009). Asymmetric Information, Stock Returns and Monetary Policy. The IUP Journal of Monetary Economics, 7 (2), 42-70.

Thorbecke, W. (1997). On Stock Market Returns and Monetary Policy. The Journal of Finance, 52 (2), 635-654.

Wong, W.-K., Khan, H., and Du, J. (2006). Do Money and Interest Rates Matter for Stock Prices? An Econometric Study of Singapore and USA. The Singapore Economic Review, 51 (1), 31-51.

Wright, F. J. (1976). Monetary Policy and The Stock Market: Is There a Direct Linkage. Financial Analysts Journal, 32 (3), 27-32. 